\title{
EFEKTIFITAS TIK UNTUK PENINGKATAN PROSES BELAJAR MENGAJAR DI PAUD, TK DAN MADRASAH DINIYAH “MAMBA'UL HISAN DUSUN SEKARGADUNG, DESA BALEREJO II, KECAMATAN PANGGUNGREJO, KABUPATEN BLITAR
}

\author{
Hermanto $^{1}$, Marsudi ${ }^{2}$, Edy Subali ${ }^{3}$ Enie Hendrajati ${ }^{4}$ \\ 1,2,3,4 UPT PMK Sosial Humaniora, FBMT, Institut Teknologi Sepuluh Nopember \\ Email: hermantoaku@gmail.com
}

\begin{abstract}
ABSTRAK
Bagi sebagian guru pra-sekolah di daerah terpencil, penggunaan teknologi sebagai media pembelajaran dalam proses belajar mengajar masih berupa mimpi. Apalagi sekolah yang dikelola merupakan sekolah yang didirikan dan dikelola oleh masyarakat secara mandiri, swadaya, dan swadana apa adanya. PAUD, TK, dan Madrasah Diniyah "Mamba'ul Hisan" Dusun Sekargadung Desa Balerejo II, Kecamatan Panggungrejo, Kabupaten Blitar adalah contoh nyata. Sekolah ini dikelola oleh individu/keluarga yang mempunyai kepedulian terhadap pendidikan di lingkungannya, yaitu Dusun Sekargadung, Desa Balerejo II, Kecamatan Panggungrejo, Kabupaten Blitar bagian selatan yang termasuk daerah tandus, terpencil, dan tertinggal. Sekolah ini dikelola apa adanya dengan segala keterbatasannya, namun tetap berusaha sebagai sekolah yang baik dan menjadi tujuan masyarakat mendapatkan pendidikan dini anak-anak mereka. Melalui program kegiatan Pengabdian Kepada Masyarakat (PKM) tim dosen Soshum ITS, guru-guru $P A \cup D, T K$, dan Madrasah Diniyah "Mamba'ul Hisan" dikenalkan kepada teknologi (literasi teknologi) sebagai media pembelajaran dalam proses belajar mengajar dalam bentuk pelatihan operasional penggunaan LCD proyektor dan pembuatan serta pengoperasian materi PPT sebagai media pembelajaran. Hasil dari pelatihan adalah pertama guru-guru mempunyai pengetahuan dan keterampilan mengoperasikan penggunaan LCD proyektor, kedua guru-guru mempunyai pengetahuan dan keterampilan dalam membuat dan mengoperasikan meteri pembelajaran dalam format PPT. Dengan diraihnya keterampilan-keterampilan literasi teknologi dalam proses pembelajaran oleh guru, maka dihasilkan metode pembelajaran yang lebih menarik, variasi bahan ajar yang kaya, yang pada ujungnya membuat peserta didik merasa senang, meningkat motivasinya, prestasinya dan kualitas pendidikannya dan membuat sekolah tersebut diminati walimurid dan masyarakat.
\end{abstract}

Kata kunci: TIK, efektifitas TIK, proses pembelajaran, media pembelajaran, pendidikan prasekolah

\section{PENDAHULUAN}

\subsection{Latar Belakang}

Profesi guru adalah profesi yang sangat mulia. Tidak hanya sebagai ujung tombak dalam mencerdeskan anak bangsa, tetapi juga penentu nasib anak bangsa di masa yang akan datang. Sebagai guru, seseorang tidak hanya mengajarkan dan membagi ilmu tetapi juga menjadi inspirasi serta teladan bagi anak didik dalam kehidupannya di kemudian hari. Terlebih, guru pada tingkat pendidikan yang paling dasar seperti Pendidikan Anak Usia Dini (PAUD) harus bisa menjadi contoh dan panutan bagi anak didiknya. Otak anak pada usia dini seperti ini sangat cepat untuk merekam apa yang dilihat dan didengar oleh orang-orang di sekitarnya. Sehingga apa yang direkam pada otak anak adalah sesuatu yang baik dan positif, maka guru PAUD harus memiliki kualitas keilmuan, keterampilan dan karakter yang baik dan positif untuk ditularkan kepada anak didiknya.

Namun demikian, pada kenyataannya masih kita akui bahwa terdapat banyak guru PAUD yang masih belum memiliki kualitas sebagaimana yang diharapkan. Sebagaimana dikatakan oleh Prof. dr. Fasli Jalal, SpGK, PhD, kepala Badan Kependudukan dan Keluarga Berencana Nasional (BKKBN) 
bahwa guru-guru PAUD di Indonesia belum semuanya memiliki pengetahuan dan kompetensi yang terstandar (Detik health, 2014). Lebih lanjut beliau mengatakan bahwa guru PAUD di Indonesia banyak yang meiliki latar belakang pendidikan yang kurang memadai, misalnya berpendidikan SMP, SMA atau hanya diploma 2 atau belum Strata 1 (S1). Lebih jauh lagi, menurutnya seorang guru PAUD diharapkan mempunyai ilmu yang memadai terutama terkait dengan pendekatan psikologis dan pedagogis dalam mendidik anak.

Pada era sekarang ini ketika teknologi, terutama teknologi informasi yang sedang berkembang begitu pesat, guru PAUD juga dituntut untuk bisa beradaptasi dengannya. Menurut Peraturan Pemerintah RI no. 74/2008 tentang guru pasal 3 menjelaskan tentang 4 kompetensi yang harus dimiliki oleh seorang guru yaitu kompetensi pedagogik, kompetensi kepribadian, kompetensi sosial dan kompetensi profesional. Salah satu unsur dalam kompetensi pedagogik adalah kemampuan dalam memanfaatkan teknologi pembelajaran (Depdiknas, 2008). Sedangkan dalam kompetensi sosial, salah satu butirnya adalah kemampuan menggunakan teknologi komunikasi dan informasi secara fungsional. Sehingga bagi seorang guru, penguasaan teknologi informasi dan komunikasi (TIK) sangat penting pada era sekarang ini.

Teknologi informasi dan komunikasi dapat dimanfaatkan sebagai salah satu jalan dalam memecahkan masalah dalam proses pembelajaran sekaligus bisa juga dipakai sebagai bentuk inovasi dalam dunia pendidikan. Guru diharapkan tidak hanya mampu menggunakan media TIK tetapi juga mampu mengembangkannya sebagai inovasi media proses pembelajaran di dalam kelas sehingga guru memiliki kreatifitas dalam memberikan materi yang sedang diajarkan kepada peserta didiknya agar mereka tidak mengalami kejenuhan dalam menyerap materi yang diberikan yang pada akhirnya berdampak pada peningkatan prestasi belajar mereka.

Terdapat banyak sekali media TIK yang bisa dimanfaatkan oleh guru dalam proses pembelajaran. Tidak hanya media presentasi, guru dalam proses pembelajaran dapat menggunakan media online maupun offline, software maupun hardware seperti perangkat laptop atau komputer, proyektor, media presentasi dan sebagainya.

Berdasarkan hasil penelitian British Association for Vedic Astrology (BAVA) di Amerika Serikat seperti yang dikutip oleh Rusman (Rusman, 2008) , hlm 95 diketahui bahwa bila seorang guru atau pendidik yang mengajar hanya menggunakan simbol verbal atau ceramah, materi yang dapat diserap oleh peserta didik hanya $13 \%$ saja dan itupun tidak bisa bertahan lama. Sedangkan apabila materi disampaikan dengan menggunakan multimedia, materi yang dapat diserap mencapai 64\% sampai $84 \%$ serta bisa bertahan lebih lama dalam ingatan siswa (Fahmi, 2014). Dengan demikian pemanfaatan medoa TIK sangat efektif sebagai alternatif pelengkap metode ceramah dalam proses pembelajaran.

Terkait dengan kondisi sekarang ini, guru-guru di sekolah PAUD, TK dan Madrasah Diniyah "Mamba'ul Hisan" Dusun Sekargadung, Desa Balerejo II, Kecamatan Panggungrejo, Kabupaten Blitar berada pada situasi yang jauh dari yang diharapkan. Daerah ini berada di daerah pinggiran pantai selatan, tetapi masih masuk wilayah Kabupaten Blitar. Untuk menuju daerah ini harus menempuh sekitar $65 \mathrm{~km}$ dari kota Blitar. Selain karena faktor geografi yang tidak menguntungkan, seperti daerah perbukitan dengan jalan yang naik turun serta berkelok-kelok. Dusun Sekargadung merupakan daerah bekas perkebunan dengan akses infrastruktur jalan yang sulit, karena jalan menuju dusun tersebut terjadi kerusakan.

Dari segi pendidikan, masyarakat dusun Sekargadung pada umumnya memiliki pendidikan rendah, ditambah lagi sosial ekonomi yang masih kurang baik. Pada umumnya, masyarakat setempat sebagai buruh tani dan petani dengan system pertanian tadah hujan. Akibatnya, masa tanam hanya bisa dua kali dan bahkan jika masa kemarau panjang hanya sekali tanam dalam satu tahun. Oleh karena keadaan geografi semacam itu kemampuan ekonomi masyarakat Sekargadung mengalami kesulitan untuk meningkatkan ekonominya. Dari beberapa kendala tersebut, guru-guru mengalami kendala tidak tersedianya sarana dan prasarana serta pelatihan TIK dalam proses pembelajaran di 
sekolah. Sekolah tidak mampu memenuhi fasilitas TIK seperti laptop/computer, LCD proyektor, serta pelatihan pengoperasian dan penggunaan software/aplikasi untuk menunjang proses pembelajaran.

Mengetahui keadaan masyarakat Sekargadung Desa Balerejo II dari berbagai hal kurang menguntungkan, tim pengabdian kepada masyarakat Institut Teknologi Sepuluh Nopember mengadakan kegiatan pengabdian di Dusun Sekargadung, Desa Balerejo II, Kecamatan Panggungrejo, Kabupaten Blitar dengan fokus pada pelatihan TIK guru-guru PAUD, TK dan Madrasah Diniyah "Mamba'ul Hisan" yang terletak di dusun tersebut. Pelatihan dilaksanakan dengan materi berupa cara mengoperasikan LCD proyektor, pembuatan materi PPT, cara mengoperasikan materi PPT, dan penggunaan program pengolah kata MS Word. Setelah pelaksanaan pelatihan guru-guru mengimplentasikan pengetahuan dan keterampilan mereka dalam proses pembelajaran yang nyata di dalam kelas.

\subsection{Tujuan}

Berdasarkan permasalahan-permasalahan yang telah dijelaskan di atas, tujuan dari kegiatan penelitian ini adalah mengetahui efektivitas dan meningkatkan penggunaan TIK sebagai sarana dalam kegiatan belajar mengajar oleh guru PAUD, TK, dan Madrasah Diniyah "Mamba'ul Hisan" Dusun Sekargadung (Balerejo II), Kecamatan Panggungrejo, Kabupaten Blitar dilihat dari tanggapan guru, murid, wali murid, dan masyarakat.

\subsection{Ruang Lingkup}

Ruang lingkup dari penelitian ini meliputi beberapa aspek, di antaranya sarana dan prasarana, pengguna yaitu guru, murid, dan wali murid serta masyarakat.

\section{- Sarana dan prasarana}

Sarana dan prasarana yang terkait dengan TIK adalah perangkat keras (hardware) seperti laptop, dan LCD proyektor dan perangkat lunak (software) seperti program presentasi (PPT) serta modul pelatihan pembuatan bahan/materi presentasi. Jumlah kelas yang dimiliki sekolah tersebut adalah tiga ruang kelas dan mushalla kecil yang bisa juga dimanfaatkan untuk kegiatan-kegiatan umum.

\section{- Murid}

Murid sekolah ini adalah siswa yang bersekolah di PAUD, TK, dan Madrasah Diniyah “Mamba'ul Hisan" Dusun Sekargadung, Desa Balerejo II, Kecamatan Panggungrejo, Kabupaten Blitar.

\section{- Guru}

Ruang lingkup guru adalah tenaga pendidik yang mengajar di sekolah. Di sekolah ini terdaftar lima guru dengan rincian tugas: 1 guru PAUD, 2 guru TK, dan 2 guru madrasah.

\section{- Wali murid}

Wali murid adalah orang tua siswa yang menyekolahkan anaknya di sekolah. Wali murid menyerahkan anak-anaknya untuk dididik dan diajari di sekolah ini dengan harapan mendapat pendidikan yang komprehensif, yakni baik pendidikan umum maupun pendidikan agama.

\section{- Masyarakat}


Masyarakat adalah orang-orang yang tinggal di lingkungan sekolah. Masyarakat di lingkungan sekolah maupun diluar lingkungan sekolah sangat mendukung keberadaan sekolah PAUD, TK, maupun madrasah. Dukungan moral dari masyarakat inilah menyulut semangat para pengelola dan guru-guru untuk berbuat lebih banyak sehingga sekolah ini menjadi sekolah yang ideal.

\section{KAJIAN LITERATUR DAN PENELITIAN TERKAIT}

\subsection{Pendidikan Anak Usia Dini}

Pada dasarnya pendidikan anak usia dini adalah bermain karena bermain merupakan suatu tuntutan dan kebutuhan bagi anak usia dini. Menurut Sudono (Sudono, 2000) bermain merupakan kegiatan yang dilakukan dengan atau tanpa alat yang menghasilkan pengertian, memberikan informasi, memberikan kesenangan serta mengembangkan imajinasi pada anak. Sedangkan belajar menurutnya adalah aktivitas mental atau psikis yang berlangsung dalam interaksi aktif dengan lingkungan yang menghasilkan perubahan dalam pengetahuan, pemahaman, keterampilan dan sikap nilai. Bermain merupakan tuntutan dan kebutuhan anak usia dini karena melalui bermain anak akan dapat memuaskan tuntutan dan kebutuhan perkembangan dimensi motorik, kognitif, kreativitas, bahasa, emosi, sosial, nilai dan sikap hidup (Moeslichatoen, 2004) (Erlina, 2009). Dengan konsep pendidikan anak usia dini seperti ini diharapkan anak memiliki kesempatan yang lebih banyak untuk bereksplorasi sehingga pemahaman mereka tentang konsep dan penertian dasar suatu pengetahuan dapat dipahami oleh anak dengan mudah.

Menurut UU no. 20/2003 tentang Sistem Pendidikan Nasional, pada Bab 1, Pasal 1, buti 14 dinyatakan bahwa "Pendidikan anak usia dini (PAUD) adalah suatu upaya pembianaan yang ditujukan kepada anak sejak lahir sampai dengan usia enam tahun yang dilakukan melalui pemberian rangsangan pendidikan untuk membantu pertumbuhan dan perkembangan jasmani dan ruhani agar anak memiliki kesiapan dalam memasuki pendidikan lebih lanjut.

Menurut Adalilla, S., (2010) PAUD merupakan salah satu bentuk penyelenggaraan pendidikan yang menitik beratkan pada peletakan dasar ke arah pertumbuhan dan perkembangan fisik (koordinasi motorik halus dan kasar), kecerdasan (daya pikir, daya cipta, kecerdasan emosi, kecerdsan spiritual) sosio emosional (sikap dan periaku serta agama), bahasa dan komunikasi sesuai dengan keunikan dan tahap-tahap perkembangan yang dilalui oleh anak usia dini (Pasaribu, 2016).

Dilihat dari fungsi, PAUD berfungsi antara lain mengenalkan peraturan dan menanamkan disiplin pada anak, mengenalkan anak pada dunia sekitar, menumbuhkan sikap dan perilaku yang baik, mengembangkan kemampuan berkomunikasi dan bersosialisasi, mengembangkan keterampilan, kreativitas, dan kemampuan yang dimiliki anak, dan menyiapkan anak untuk memasuki pendidikan selanjutnya.

\subsection{Teknologi Informasi dan Komunikasi (TIK) dan Pendidikan (PAUD)}

Teknologi Informasi dan Komunikasi (TIK) adalah suatu sistem teknologi yang terdiri dari sistem informasi dan komunikasi. Teknologi informasi merupakan suatu studi atau penggunaan peralatan eketronik terutama computer untuk menyimpan, menganalisa dan mendistribusikan informasi apa saja, termasuk kata-kata, bilangan dan gambar (Zeldra, 2015). Sedangkan teknologi komunikasi adalah perangkat teknologi yang terdiri dari perangkat keras (hardware), perangkat lunak (software), proses dan sistem yang digunakan untuk membantu proses komunikasi berhasil. Menurut, teknologi komunikasi menekankan pada penggunaan perangkat teknologi elektronika pada aspek ketercapaian tujuan dalam proses komunikasi. Sehingga data dan informasi yang diolah dengan teknologi informasi harus memenuhi kriteria komunikasi yang efektif (Zeldra, 2015).

TIK memiliki peran yang sangat penting dalam pendidikan, tidak hanya sebagai pendukung kinerja sistem pendidikan, tetapi juga bermanfaat sebagai media pendidikan terutama dalam proses belajar mengajar. Proses pembelajaran pada hakekatnya merupakan proses komunikasi yaitu proses 
menyampaikan pesan dari sumber pesan (guru) melalui saluran atau media tertentu ke penerima pesan (murid). Pesan, sumber pesan, saluran/media dan penerima pesan merupakan komponen utama dalam komunikasi. Dilihat dari karakteristiknya, saluran/media terdiri dari empat bentuk yaitu media audio (suara/pendengaran), media visual (gambar/penglihatan), media audio visual (suara dan gambar) serta multimedia (multi indera).

Sebagai usaha mengembangakan kemampuan individu dalam penggunaan TIK secara praktis maka perlu dikenalkan sejak usia dini. Pengembangan kemampuan anak usia dini dalam TIK harus tetap dilakukan dengan konsep pendidikan anak usia dini yaitu belajar melalui bermain. Materi belajar yang diberikan juga harus bervariasi dengan berbagai karakteristik TIK sebagi media pembelajaran agar imajinasi dari anak tersebut berkembang sehingga semakin meningkatkan kemampuan intelektual dan emosional mereka.

\section{DATA PENELITIAN}

Data penelitian diperoleh dari hasil pengamatan langsung dan wawancara. Data terdiri dari sarana dan prasarana dan stakeholder yaitu guru, murid dan wali murid serta masyarakat di sekitar PAUD, TK, dan Madrasah Diniyah "Mamba'ul Hisan" dan tokoh masyarakat.

Dari pengamatan lapangan di ketahui bahwa di PAUD, TK dan Madrasah Diniyah "Mamba'ul Hisan" terdapat satu buah laptop kondisi baru dan sebuah proyektor LCD dalam kondisi baru pula. Sekolah tersebut belum memiliki layar LCD.

Data wawancara berupa transkrip yang diperoleh dari wawancara yang dilakukan terhadap guru, murid, dan wali murid serta masyarakat termasuk tokoh masyarakat.

\section{PEMBAHASAN}

\subsection{Sarana dan prasarana}

Sarana dan prasarana yang terkait dengan TIK adalah perangkat keras (hardware) seperti laptop, dan LCD proyektor dan perangkat lunak (software) seperti program presentasi (PPT) serta modul pelatihan pembuatan bahan/materi presentasi. Dari hasil pengamatan ketersediaan sarana dan prasarana masih sangat terbatas, yakni hanya memiliki satu laptop dan satu LCD proyektor. Pada hal jumlah guru di sekolah tersebut terdapat lima guru. Jika hanya ada satu laptop dan satu LCD maka kebutuhan sarana pembelajaran di sekolah tersebut sangat kurang. Dari hasil wawancara, pemanfaatan laptop dan LCD termasuk kurang efektif. Hal ini disebabkan kurangnya pengetahuan dan keterampilan dalam mengoperasikan sarana tersebut. Namun demikian, pihak pimpinan sekolah berkeinginan sekali untuk mengupayakan dan memaksimalkan, baik sarana maupun tenaga pendidiknya. Dengan harapan proses pembelajaran bisa berjalan lancar dan menghasilkan didikan yang maksimal dan memuaskan dari berbagai pihak.

Untuk kelancaran proses belajar dan memaksimalkan kinerja para guru setidaknya setiap guru memiliki satu buah unit laptop. Demikian pula LCD proyektor ada pada setiap kelas dan terpasang permanen, sehingga kalau dibutuhkan tidak lepas pasang dan berpindah-pindah. Selain merepotkan, juga rentan rusak. Demikian juga layar proyektor sebaiknya ada pada setiap ruang dan terpasang permanen. Kalaupun tidak ada layar bisa menggunakan tembok atau papan tulis tetapi tempatnya harus benar-benar siap dan tidak ada gangguan seperti tulisan atau hiasan/ornament pada tembok. Oleh sebab itu, kepedulian dan bantuan dari berbagai pihak sangat diharapkan sehingga sekolah ini bisa melaksanakan proses pembelajaran dengan baik.

Selain keterbatasan-keterbatasan yang telah dijelaskan di atas, supaya TIK lebih sempurna dalam pemanfaatannya, terutama terkait fasilitas multimedia, maka pengeras suara perlu disediakan. Dapat dibayangkan, pengajaran menggunakan multimedia tanpa pengeras suara akan sangat kurang sempurna. Oleh karena itu, agar proses belajar dapat berlangsung dengan baik lagi maka pengeras suara perlu disediakan pada setiap ruang kelas. Demikianlah beberapa keterbatasan 
di sekolah ini, namun dengan adanya penambahan beberapa model pembelajaran dengan menggunakan TIK, baik murid, wali murid, guru, dan masyarakat sangat senang dan merasa mendapatkan pengetahuan pembelajaran yang modern.

\subsection{Guru}

Ada lima orang tenaga pengajar di PAUD, TK dan Madrasah Diniyah "Mamba'ul Hisan". Mereka adalah tenaga pengajar yang bersifat sukarela. Pendidikan mereka adalah SMA dan tidak memiliki ijazah/sertifikat pendidik. Karena kepedualian dan semangat, mereka rela untuk mengajar dengan kondisi dan imbalan apa adanya. Walaupun saat ini lima orang guru belum memiliki sertifikat pendidik, dua guru sekolah tersebut sedang studi lanjut untuk mendapatkan hak sebagai pendidik. Persyaratan tenaga pendidik di sekolah ini terus diupayakan, misalnya mengikuti kursus-kursus tentang pembelajaran PAUD dan TK di kecamatan dan kabupaten. Upaya-upaya seperti ini terus dilakukan oleh sekolah walaupun menggunakan biaya pribadi dengan harapan mendapatkan pengetahuan yang cukup meskipun dari segi persyaratan sertifikasi belum terpenuhi.

Seperti telah disampaikan di atas, tentang implementasi TIK dalam proses pembelajaran, mereka menyatakan sangat senang. Mereka mengakui bahwa sebelum adanya program pengabdian masyarakat ITS mereka tidak memiliki laptop dan LCD proyektor. Dalam proses pembelajaran sebelumnya mereka menggunakan metode tradisional berupa cerita atau ceramah dalam menyampaikan materi. Namun, sekarang mereka menggunakan materi yang tersedia di dalam laptop meskipun masih kurang ideal. Menurut para guru dengan TIK, mereka merasakan berbagai kemudahan seperti materi siap setiap saat, tampilan lebih menarik, membuat materi pembelajara sekali dan dipakai berkali-kali, sehingga menghemat waktu dan tenaga serta biaya dalam persiapan mengajar. Banyak file materi yang bisa disimpan di dalam laptop yang setiap saat bisa dibuka kembali dan dipakai sebagai bahan mengajar.

Menurut pendapat para guru, selain kelebihan yang mereka rasakan dari TIK, mereka juga merasakan adanya hambatan-hambatan dalam implementasi TIK seperti keterbatasan pengetahuan tentang penggunaan sarana dan prasarana yang ada. Mereka merasa tidak memiliki keterampilan untuk mendesain dan membuat materi sendiri. Mereka membutuhkan pelatihan dan bimbingan yang kontinu tentang pemanfaatan berbagai kelebihan pada TIK. Selain itu, karena letak desa mereka jauh dari kota dan terpencil, akses internet juga relatif sulit.

Penerapan TIK dalam proses pembelajaran di sekolah juga dapat meningkatkan citra sekolah di mata siswa, wali murid, dan msyarakat. Apabila semua guru memiliki pengetahuan dan keterampilan TIK yang cukup baik, maka kondisi itu akan meningkatkan kualitas lulusan dan sekolah meskipun ada di daerah terpencil, jauh dari kota.

\subsection{Murid}

Dengan penerapan TIK dala proses pembelajaran, murid-murid sangat senang karena guru mengajar dengan cara yang lebih menarik dan variatif. Ada materi yang bisa bergerak dan berwarna dan ada suara yang menyenangkan. Perhatian siswa terhadap pelajaran lebih fokus dan daya pemahaman terhadap materi yang diberikan juga lebih baik. Dengan media semacam itu, murid mampu menceritakan kembali pelajaran yang diterima dengan lancar. Semakin banyak media pembelajaran yang dimanfaatkan akan semakin baik hasil pembelajarannya.

\subsection{Wali murid}

Bagi wali murid, sekolah yang berkualitas adalah pilihan terbaik untuk anak-anak mereka bersekolah dan menuntut ilmu. Sekolah yang baik menjamin kualitas proses pembelajaran yang diselenggarakan berjalan dengan baik pula. Proses pembelajaran yang baik bisa berlangsung apabila terdapat sistem pembelajaran yang baik, sarana dan prasarana yang baik, guru yang baik dan kurikulum yang baik, serta manajemen yang baik. 
Dengan adanya penerapan TIK dalam proses pembelajaran di sekolah oleh guru, wali murid memandangnya sebagai suatu peningkatan. Sebagai sekolah di daerah terpencil, maka penerapan TIK sebagai suatu kemajuan yang berdampak pada kepercayaan wali murid untuk menyekolahkan anak mereka di sekolah ini. Mereka tidak perlu memikirkan untuk mengirim anak mereka sekolah di wilayah lain, atau bahkan ke kota. Jika wali murid harus menyekolahkan ke kota maka mereka akan mengeluarkan biaya lebih banyak, waktu yang lama untuk antarjemput, dan masih banyak lagi sisi kekurangannya. Oleh karena itu, wali murid merasa bangga apbila anak mereka bisa bersekolah di sekolah yang berada di desanya sendiri dengan kualitas guru dan proses pembelajaran yang baik dan modern.

\subsection{Masyarakat}

Masyarakat Dusun Sekargadung, Desa Balerejo II, Kecamatan Panggungrejo, Kabupaten Blitar adalah masyarakat petani yang hidup dengan mengandalkan pertanian sebagai mata pencaharian. Dusun Sekargadung termasuk daerah terpencil yang jauh dari kota Blitar maupun kota Wlingi, sebagai kota terbesar kedua sebelum Kota Blitar dari arah kecamatan Panggungrejo.

Masyarakat Sekargadung sebagai masyarakat yang tinggal di daerah terpencil, menjalani kehidupan yang sederhana dan menghabiskan sebagian besar waktunya bertani di sawah tadah hujan atau lading perbukitan. Terkait pendidikan, mereka tidak terlalu menjadikan pendidikan sebagai prioritas. Hal ini terjadi karena sebagian besar pendidikan mereka sebatas sekolah dasar (SD) atau sebagian kecil hanya sekolah menengah pertama (SMP) dan jarang yang melanjutkan ke SMA apalagi perguruan tinggi.

Menurut sebagian kecil tokoh masyarakat dusun Sekargadung, pendidikan sangat penting bagi generasi muda. Mereka mempunyai harapan besar akan masa depan anak-anak mereka sehingga bisa hidup dan memiliki masa depan yang lebih baik. Masyarakat menyambut baik dan sangat senang dengan adanya peningkatan mutu guru dan sekolah yang bisa mengimplementasikan TIK dalam proses pembelajarannya. Sekolah di daerah yang jauh dari modernisasi yang berada di dusun dan pinggiran pantai tetapi maju menjadikan masyarakat merasa bangga karena bisa mengangkat nama baik dusun. Masyarakat tidak perlu menyekolahkan anak mereka ke luar dusun, bahkan mereka berharap masyarakat dari luar dusun menyekolahkan anak mereka di dusun Sekargadung.

\section{PENUTUP}

\subsection{Kesimpulan}

Ketersediaan dan pelaksanaan program pelatihan peningkatan keterampilan TIK bagi para guru yang mengajar di sekolah PAUD, TK dan Madrasah Diniyah "Mamba'ul Hisan" telah sangat membantu dalam peningkatan kualitas mereka dalam meningkatkan mutu pembalajaran. Meskipun hanya ada satu set laptop dan satu proyektor tetapi sudah sangat membantu dalam memperkaya dan melakukan inovasi proses pembelajaran. Murid juga merasa sangat senang dan tambah termotivasi dalam belajar. Selain itu mereka tidak merasa bosan dengan pelajaran yang disampaikan dan bisa lebih memahami pelajaran dengan lebih baik. Selanjutnya, wali murid juga merasa senang dengan adanya media TIK serta kegiatan pembelajaran yang disampaikan dengan menggunakan TIK di sekolah yang dapat menjadikan sekolah tempat anak mereka memulai pendidikan menjadi berkualitas. Begitu pula dengan masyarakat yang merasa bangga karena peningkatan mutu guru dan sekolah menjadikan nama dusun mereka juga semakin terkenal.

\subsection{Saran}

Penerapan TIK dalam pembelajaran sangat penting maka disarankan antara lain, pertama guru dan pengelola sekolah memikirkan kelanjutan dari implementasi TIK ini karena perkembangan TIK sangat dinamis dan cepat sehingga di tuntut para guru untuk bisa mengikutinya. Kedua, terdapat 
banyak sekali program yang bisa diaplikasikan namun lebih baik apabila ada sambungan internet untuk akses mendapatkannya. Ketiga, peningkatan keterampilan dilakukan dengan terus berlatih dan mengeksplorasi berbagai fasilitas teknologi yang tersedia. Keempat, perawatan perlu diperhatikan karena peralatan elektronik yang dipakai oleh banyak orang tanpa memperhatikan prosedur yang benar akan rentan mengalami kerusakan atau gagal fungsi. Pihak pemerintah, khususnya dinas pendidikan setempat turut membina lebih intensif. Sekolah ini berstatus sekolah swasta. Jika pihak dinas pendidikan kurang keberpihakannya maka tujuan program pendidikan nasional juga akan gagal. Pendidikan di daerah pinggiran atau daerah-daerah terpencil seperti ini perlu mendapatkan perhatian khusus agar tidak tertinggal jauh dengan daerah-daerah perkotaan. Dengan adanya perhatian khusus, termasuk dana pendidikan, sekolah-sekolah yang berada di daerah terpencil tetap perlu mendapatkan pendidikan yang sama dengan daerah perkotaan.

\section{DAFTAR REFERENSI}

Depdiknas. Peraturan Pemerintah Republik Indonesia Nomor74 Tahun2008 Tentang Guru, Pub. L. No. 74, 1 (2008). Indonesia. Retrieved from http://peraturan.go.id/pp/nomor-74-tahun-200811e44c4f529f36a0a226313232303239.html

Detik health. (2014). Kualitas Guru Masih Kurang, Masalah Utama PAUD di Indonesia. Retrieved July 30, 2018, from https://health.detik.com/anak-dan-remaja/d-2655128/kualitas-guru-masihkurang-masalah-utama-paud-di-indonesia

Erlina, B. (2009). Peningkatan Kemampuan Berhitung Melalui Permainan Keranjang Tempurung Dan Biji Salak Di Taman Kanak-Kanak PK3A Taeh Baruah Kecamatan Payakumbuh. Pesona Paud, I(1), 1-11. Retrieved from http://download.portalgaruda.org/article. php?article=100794\&val=1492

Fahmi, F. (2014). Pentingnya Penggunaan media belajar TIK oleh Guru | Pustaka Online. Retrieved July 24, 2018, from http://pustaka-downloads.blogspot.com/2016/01/pentingnya-penggunaanmedia-belajar-tik.html

Moeslichatoen. (2004). Metode Pengajaran di TK (1st ed.). Jakarta.

Pasaribu, M. (2016). Pengertian,Fungsi dan Tujuan Pendidikan Anak Usia Dini (PAUD) | Kumpulan Artikel. Retrieved July 18, 2018, from http://mangihot.blogspot.com/2016/12/pengertianfungsi-dan-tujuan-pendidikan.html

Rusman. (2008). Manajemen Kurikulum "Seri Manajemen Sekolah Bermutu." Bandung: Mulia Mandiri Press.

Sudono, A. (2000). Sumber belajar dan alat permainan untuk pendidikan anak usia dini - Anggani Sudono - Google Buku. Retrieved July 10, 2018, from https://books.google.co.id/books?id=ZLHtwVzHuaoC\&pg=PA16\&source=gbs_selected_pages\&c $\mathrm{ad}=3 \# \mathrm{v}=$ onepage $\& \mathrm{q} \& \mathrm{f}=\mathrm{false}$

Zeldra, G. U. (2015). TIK pada ANAK USIA DINI. Retrieved July 27, 2018, from http://ghitautami.blogspot.com/2015/12/tik-pada-anak-usia-dini.html 